Pak. j. sci. ind. res. Ser. B: biol. sci. 201558 (2) 111-113

Short Communication

\title{
High Heritability in a Resistant Barley Genetic Source to Spot Blotch (Cochliobolus sativus)
}

\author{
Mohammad Imad Eddin Arabi*, Antonious Al-Daoude, Amina Shoaib and \\ Mohammad Jawhar \\ Department of Molecular Biology and Biotechnology, AECS, P. O. Box 6091, Damascus, Syria
}

(received June 3, 2014; revised December 23, 2014; accepted January 14, 2015)

\begin{abstract}
The objective of the present research was to assess and understand the heritability of the resistant barley genetic source cv. Banteng to spot blotch SB disease caused by Cochliobolus sativus. A cross was made between this resistant cultivar and the universally susceptible cv. WI 2291. Analysis of variance for the studied trait indicated highly significant differences among cultivars. High broad sense heritability was found $(H \approx 88 \%)$. However, in all cases, the results obtained for the $\mathrm{F}_{2}$ plants demonstrated that the observed segregation pattern fitted 1:15 ratios.
\end{abstract}

Keywords: Hordeum vulgare, Cochliobolus sativus, fungus resistance, inheritance

Spot blotch (SB) caused by Cochliobolus sativus (Ito \& Kurib.) Drechsler ex Dastur [anamorph: Bipolaris sorokiniana (Sacc.) Shoem.] is economically one of the most important fungal diseases of barley (Hordeum vulgare L.) throughout the world (Mathre et al., 2003).

The economic damage caused by SB and planting of resistant genotypes has been studied extensively by many researchers (Zhou and Steffenson, 2013; Ghazvini and Tekauz, 2008; Joshi et al., 2007a; Bilgic et al., 2006; 2005; Arabi, 2005a; Arabi and Jawhar, 2004; 2003; Steffenson et al., 1996).

The present study therefore, was initiated to investigate the inheritance pattern of SB resistance in the German barley Banteng cultivar to design suitable strategies to enhance resistance of barley cultivars.

Single plant selections of resistant (Banteng) and susceptible (WI2291) cultivars were multiplied and used in the cross. Resistant parent Banteng (a germplasm cultivar introduced from Germany) was crossed with the universal susceptible WI2291 (originated from the Waite Institute, Glen Osmond, Australia) which is otherwise higher yielding with good agronomic performance.

Parents and $\mathrm{F}_{1}$ progenies (29 plants) were evaluated for resistance to SB under an induced epiphytotic created in the field at station, west of Damascus, Syria under rainfed conditions (500mm rainfall). Seeds were planted in a randomised complete block design, with three

*Author for correspondence; E-mail: ascientific@aec.org.sy replicates. Plots of the $\mathrm{F}_{1}$ generation consisted of two $2-\mathrm{m}$ rows seeded $25 \mathrm{~cm}$ apart with $30 \mathrm{~cm}$ between plots. The susceptible barley cultivar WI 2291 was planted in the alleys and borders, two weeks before sowing the experiment to enhance the spread of disease. Soil fertilizers were drilled before sowing at a rate of $50 \mathrm{~kg} / \mathrm{ha}$ urea $(46 \% \mathrm{~N})$ and $27 \mathrm{~kg} /$ ha superphosphate $(33 \% \mathrm{P})$. The progenies of the cross were advanced to the $\mathrm{F}_{2}$ generation (457 plants) following the method described by Joshi et al. (2004) where a random plant in each generation from each line was harvested for advancing the generation.

A mixture of equal ratio of pure aggressive isolates of C. sativus (Arabi and Jawhar, 2004) was used to inoculate the parents as well as plants of the $\mathrm{F}_{1}$ and $\mathrm{F}_{2}$ generation. A spore suspension (approximately $2 \times 10^{4}$ spores $/ \mathrm{mL}$ ) containing the surfactant Tween 20, was uniformly sprayed onto plants during the evening hours by using a hand-held atomizer, then plants were covered with polyethylene for 3 days to maintain humidity for infection and subsequent disease development (Joshi et al., 2007a; 2007b).

Percentages were transformed into a 1-4 scale. Cultivars that scored less than $26 \%$ were considered resistant, between 26 and $50 \%$ as moderately susceptible; between 60 and $70 \%$ as susceptible, and those having higher than 70 as highly susceptible (Joshi et al., 2007a; 2007b).

Statistical analysis. For every line, disease scores of all the plants including the most susceptible and most resistant ones were recorded. Broad-sense heritability 
$\left(h^{2} b\right)$ was used to eliminate the influence of environment on the expression of disease severity (Mulitze and Baker, 1995) and computed as follows:

$\mathrm{h}^{2}{ }_{\mathrm{b}}=\sigma_{\mathrm{G}}^{2} / \sigma_{\mathrm{P}}^{2} \times 100, \sigma_{\mathrm{G}}^{2}=\sigma_{\mathrm{P}}^{2}-\sigma_{\mathrm{E}}^{2}, \sigma_{\mathrm{E}}^{2}=\sigma_{\mathrm{P}_{1}}^{2}+$ $\sigma_{P_{2}}^{2}+\sigma_{F_{1}}^{2} / 3, \sigma_{P}^{2}=\sigma_{G}^{2}-\sigma^{2}{ }_{E}$

where:

$\sigma_{P}^{2}=$ phenotypic; $\sigma_{E}^{2}=$ environmental; $\sigma_{G}^{2}=$ genetic; $\sigma_{\mathrm{P}_{1}}^{2}=$ Banteng; $\sigma_{\mathrm{P}_{2}}^{2}=$ WI 2291 variance.

Significant differences $(\mathrm{p}=0.05)$ in mean severity values were detected between the two barley cultivars. The cv. Banteng had a mean disease severity of 13.45 $\%$, whereas the susceptible cv. WI 2291 had a mean disease severity $73.44 \%$ (Table 1 ). The general combining ability (GCA) mean square was significant at $p=0.05$, which shows the variability of (GCA) of the parent. Estimates of GCA effects of each parental genotype are presented in Table 1. Compared to the parents, the SB severity of the $29 \mathrm{~F}_{1}$ plants appeared to be intermediate (Fig. 1), indicating the absence of dominance for the genes governing resistance.

Moreover, $\mathrm{F}_{2}$ progeny distributions in the cross (Fig. 1) indicated that resistance genes interacted in an additive manner. $\mathrm{F}_{2}$ progeny exhibited a wide range of $\mathrm{SB}$ severities from 2 to $88 \%$ (Fig. 1). As discrete classes were observed in the distribution of SB reaction in the $\mathrm{F}_{2}$, the plants were classified within parental classes using phenotypic values observed for the parents grown in the same environment. This was only applicable to the class of the resistance of parent $(\leq 20 \%)$, as the range of variation of the standard resistance parent was similar to that of the $F_{1}$. However, in all cases, the results obtained for the $\mathrm{F}_{2}$ plants demonstrated that the observed segregation pattern fitted $1: 15\left(\mathrm{X}^{2}=7.11 ; \propto=0.10\right)$ ratios.

Table 1. Range and mean spot blotch (SB) severity (\%) of barley parents during two years of testing under different field conditions, and the general combining ability (GCA) estimates in the $\mathrm{F}_{1}$ generation ${ }^{\mathrm{y}}$

\begin{tabular}{lllllll}
\hline \hline & & \multicolumn{2}{c}{ SB reaction } & & \multicolumn{2}{c}{ GCA } \\
\cline { 6 - 7 } \cline { 5 - 6 } Genotype & Origin & Range & Mean & & Seedling & Adult plants \\
\hline Banteng & Germany & $1.14-22$ & 13.45 & & $-0.90^{*}$ & $-0.92^{*}$ \\
W1229 & Australia & $54-90$ & 73.44 & & $0.75^{*}$ & $0.72 *$ \\
& & & & 0.18 & 0.15 \\
$\mathrm{~F}_{1}$ & & $35-50$ & 42.00 & & \\
$\mathrm{~F}_{2}$ & & $6-80$ & 41.64 & & \\
\hline \hline
\end{tabular}

*Significant at $\mathrm{p}=0.05,{ }^{\mathrm{y}}=$ Arabi, 2005a
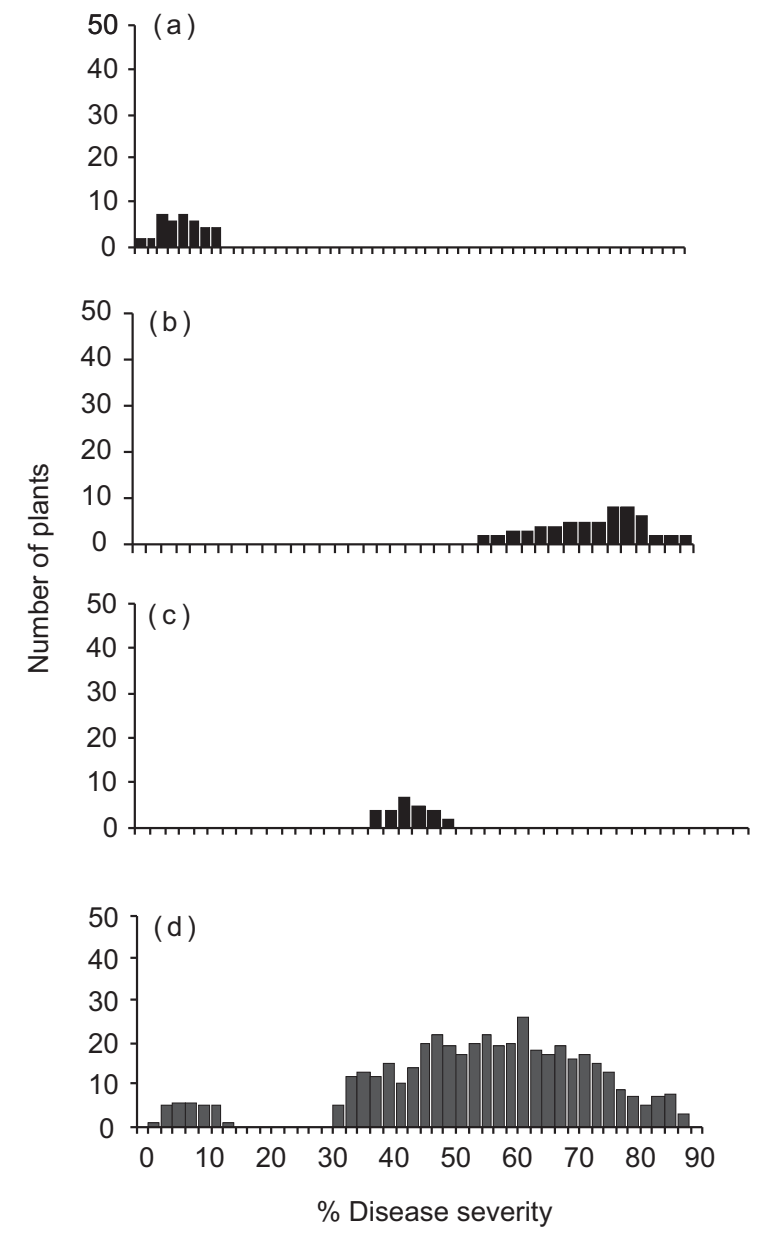

Fig. 1. Histogram of $\%$ disease severity in $\mathrm{cv}$. Banteng (a), cv. WI 2291 (b), $F_{1}$ (c) and $\mathrm{F}_{2}(\mathrm{~d})$.

Chromosomes $1 \mathrm{~S}$ and $5 \mathrm{~S}$ have been identified in barley as harboring loci for SB resistance at the adult stage. Information regarding the genes controlling durable resistance is of a paramount importance to breeders. Some of the previous studies concerning the inheritance of SB resistance in barley also indicated the control by many genes (Kuldeep et al., 2008), who reported that the heritabilities of SB resistance were moderately high and ranged from 0.77 to 0.83 across four environments.

The results of the present study indicate that the heritability of resistance in cv. Banteng was high at $88 \%$. Thus, this cultivar should be considered as a possible donor in future breeding efforts. Since heritability was high, effective selection could be applied in early generations. Furthermore, the cv. Banteng was resistant to net blotch, barley stripe (Arabi, 2005b) and powdery mildew (Arabi and Jawhar, 2012), which could give it special interest in barley breeding programmes. 


\section{References}

Arabi, M.I.E., Jawhar, M. 2012. Expression of resistance to Blumeria graminis in barley genotypes (Hordeum vulgare L.) under field and controlled conditions. Journal of Plant Biology Research, 1: 107-112.

Arabi, M.I.E. 2005a. Inheritance of partial resistance to spot blotch in barley. Plant Breeding, 124: 605-607.

Arabi, M.I.E., 2005b. Diallel analysis of barley for resistance to leaf stripe and impact of the disease on genetic variability for yield components. Euphytica, 145: 161-170.

Arabi, M.I.E., Jawhar, M. 2004. Identification of Cochliobolus sativus (spot blotch) isolates expressing differential virulence on barley genotypes in Syria. Journal of Phytopathology, 152: 461-464.

Arabi, M.I.E., Jawhar, M. 2003. Pathotypes of Cochliobolus sativus (spot blotch) on barley in Syria. Journal of Plant Pathology, 85: 193-196.

Bilgic, H., Steffenson, B.J., Hayes, P.M. 2006. Molecular mapping of loci conferring resistance to different pathotypes of the spot blotch pathogen in barley. Phytopathology, 96: 699-708.

Bilgic, H., Steffenson, B.J., Hayes, P.M. 2005. Comprehensive genetic analyses reveal differential expression of spot blotch resistance in four populations of barley. Theoretical of Applied Genetics, 111: 1238-1250.

Ghazvini, H., Tekauz, A. 2008. Host-pathogen interactions among barley genotypes and Bipolaris sorokiniana isolates. Plant Disease, 92: 225-233.

Joshi, A.K., Kumari, M., Singh, V.P., Reddy, C.M., Kumar, S., Rane, J., Chand, R. 2007a. Stay green trait: Variation, inheritance and its association with spot blotch resistance in spring wheat (Triticum aestivum L.). Euphytica, 153: 59-71.

Joshi, A.K., Ortiz-Ferrara, G., Crossa, J., Singh, G., Alvarado, G., Bhatta, M.R., Duveiller, E., Sharma, R.C., Pandit, D.B., Siddique, A.B. 2007b. Associations of environments in South Asia based on spot blotch disease of wheat caused by Cochliobolus sativus. Crop Science, 47: 1071-1084.

Joshi, A.K., Chand, R., Kumar, S., Singh, R.P. 2004. Leaf tip necrosis: A phenotypic marker associated with resistance to spot blotch disease in wheat. Crop Science, 44: 792-796.

Kuldeep, T., Nandan, R., Kumar, U., Prasad, L.C., Chand, R., Joshi, A.K. 2008. Inheritance and identification of molecular markers associated with spot blotch (Cochliobolus sativus L.) resistance through microsatellites analysis in barley. Genetics Molecular Biology, 31: 734-742.

Mathre, D.E., Johnston, R.H., Grey, W.E. 2003. Diagnoses of common root rot of wheat and barley. Online. Plant Health Progress doi: 10.1094/PHP2003-0819-01-DG.

Steffenson, B.J., Hayes, P.M., Kleinhofs, A. 1996. Genetics of seeding and adult plant resistance to net blotch (Pyrenophora teres $f$. teres) and spot blotch (Cochliobolus sativus) in barley. Theoretical of Applied Genetics, 92: 552-558.

Zhou, H.B., Steffenson, B.J. 2013. Genome-wide association mapping reveals genetic architecture of durable spot blotch resistance in US barley breeding germplasm. Molecular Breeding, 32: 139-154. 